\section{Response to Artificial Infection by Phytophthora cactorum of Four Apple Scion Cultivars on Three Rootstock}

\author{
R.S. Utkhede and E.M. Smith \\ Agriculture Canada Research Station, Summerland, British Columbia, \\ VOH 1ZO, Canada
}

Additional index words. disease resistance, disease tolerance, crown rot, collar rot, root rot, Malus domestica

\begin{abstract}
A 10-year field experiment was conducted on 20-year-old apple trees (Malus domestica Borkh.) inoculated with Phytophthora cactorum (Leb. \& Cohn) Schroet. to study the influence of the scion cultivar on rootstock susceptibility. The rootstock MM.111 was less susceptible to $P$. cactorum than M.7 when 'Golden Delicious' was the scion, but there were no differences when 'Delicious', 'Haroldred Delicious', or 'McIntosh' were the scions. Similarly, the rootstock M.26 was less susceptible than M.7 when 'McIntosh' was the scion, but there were no differences when 'Delicious', 'Haroldred Delicious', or 'Golden Delicious' were the scions. These results suggest that the influence of scions on rootstock susceptibility to $P$. cactorum crown rot is variable.
\end{abstract}

Phytophthora cactorum, an important pathogen of apple trees, causes crown rot in mature apple orchards in British Columbia (Utkhede, 1986). This pathogen is responsible for tree deaths in most apple-growing regions of the world (McIntosh, 1975). Outbreaks of crown rot are random and depend on excess soil water, suitable temperatures, and host susceptibility (Sewell and Wilson, 1974).

Marked differences in the resistance of apple rootstock to crown rot have been noted (Barritt et al., 1990; McIntosh, 1975; Sewell and Wilson, 1959; Utkhede and Quamme, 1988). M.9 and M.4 are resistant, but not immune; MM.111 and M.7 are moderately resistant and MM.104, MM.106, and M.26 are susceptible to crown rot. Several assays have been developed to assess resistance. Some breeding programs include screening for resistance at the seedling stage (Cummins and Aldwinckle, 1982; Tobutt, 1985), although the value of such tests is uncertain (Harris and Tobutt, 1986). Inoculating cut woody shoots has been used in various forms by many workers to measure the resistance of apple trees to P. cactorum (Dakwa and Sewell, 198 1; McIntosh, 1975)

Several researchers have been frustrated by their inability to produce infection through artificial inoculation under orchard conditions. Borecki and Millikan (1969) found that inoculating 4-year-old budded rootstock with an agar plug containing $P$. cactorum was the most reliable method under field conditions. Utkhede (1984) infected 2-year-old MM.106 rootstocks under field conditions with 5-mm agar plugs

Received for publication 15 June 1992. Accepted for publication 23 Dec. 1992. Summerland Research Station contribution no. 799. The cost of publishing this paper was defrayed in part by the payment of page charges. Under postal regulations, this paper therefore must be hereby marked advertisement solely to indicate this fact. containing actively growing $P$. cactorum. Inducing crown rot experimentally in 17 -yearold rootstock under orchard conditions has been only slightly successful (Harris, 1990).

Variations in cultivar resistance to crown rot associated with rootstock were demonstrated by Dakwa and Sewell (1981) and Sewell and Wilson (1973a, 1973b).

We studied crown rot in an established orchard by inoculating trees of four scions on three rootstock. Trees were 20 years old at the start of the experiments in 1981.

The trial was conducted at the Kelowna Substation of Agriculture Canada Research Station, Summerland, on soil with pH 6.9. Graft unions were $\approx 30 \mathrm{~cm}$ above soil (gravelly sandy loam) level. The cultivars were 'Delicious', 'Golden Delicious', 'Haroldred Delicious', and 'McIntosh', and rootstock were MM.111, M.7, and M.26. Eight single-tree replicates were arranged in randomized blocks with split plots. The three rootstock were main plots, and four scion cultivars were subplots. Tree spacing was $5 \times 3 \mathrm{~m}$.

Each tree was inoculated, as described by Borecki and Millikan (1969), on 20 Aug. 1981 rootstocks in an established orchard. test at $P \leq 0.05$. at $P \leq 0.05$. and thereafter in the second week of June every year until 1988 with four 5-mm agar plugs containing actively growing $P$. cactorum. The soil was removed from the crown region to a depth of $\approx 6 \mathrm{~cm}$, and inoculum plugs were inserted in holes $(5 \mathrm{~mm}$ in diameter, $2 \mathrm{~mm}$ deep) made with a cork borer. The soil was replaced and all trees were irrigated immediately after inoculation. Thereafter, the trees were irrigated for $8 \mathrm{~h}$ every 10 days with under-tree sprinklers between the trees. Normal insect, weed, and foliar disease control measures were carried out uniformly over all treatments.

Fruit yields were measured from 1982 to 1988. After the trial was terminated in 1990 , the tree tops were cut off with a chainsaw, and the stumps were removed by a tractor equipped with a backhoe. Roots were evaluated visually for crown rot damage immediately after removing them. The evaluation was based on the extent of infection, expressed as a percentage, of the crown region of the tree.

The presence of $P$. cactorum in the bark and roots of infected trees was confirmed using the method of Matheron et al. (1988) and a selective medium (10 plates per sample) containing cornmeal agar amended with $5 \mathrm{mg}$ Pimaricin, $300 \mathrm{mg}$ vancomycin hydrochloride, and $25 \mathrm{mg}$ of pentachloronitrobenzene per liter. Infected bark samples from the margins of active cankers on the trunk were processed in a similar manner. The plates were examined daily for 5 to 7 days for $P$. cactorum growth. Typical $P$. cactorum colonies were examined under a microscope to confirm infection by the pathogen. Data were analyzed by general linear model (GLM) procedures (SAS Institute, Cary, N.C.). All data were analyzed for statistical significance by the GLM procedure. Duncan's new multiple range test was used to compare treatments when analysis of variance (ANOVA) showed significant differences among means.

Bark and root samples from all trees with typical crown rot symptoms contained viable $P$. cactorum. Phytophthora cactorum was not isolated from any of the healthy crown and root tissues. The range of infection was from $10 \%$ to $100 \%$ in individual trees.

Degree of crown rot varied with the scion cultivar (Table 1). MM.111 was less suscep-

Table 1. Phytophthora cactorum crown rot infection (percent crown area af fected) induced by inoculating 20 -year-old trees of four cultivars on three

\begin{tabular}{lcccc}
\hline & \multicolumn{4}{c}{ Scion cultivar } \\
\cline { 2 - 5 } Rootstock & Delicious & Delicious & Delicious & McIntosh \\
\hline \multirow{3}{*}{ MM.111 } & \multicolumn{4}{c}{ Crown rot infection (\%) } \\
& $81.4 \mathrm{a}^{\mathrm{z}}$ & $55.6 \mathrm{~b}$ & $73.7 \mathrm{a}$ & $75.6 \mathrm{ab}$ \\
M.7 & $\mathrm{A}^{\mathrm{y}}$ & $\mathrm{B}$ & $\mathrm{AB}$ & $\mathrm{AB}$ \\
& $72.5 \mathrm{a}$ & $87.0 \mathrm{a}$ & $81.9 \mathrm{a}$ & $86.5 \mathrm{a}$ \\
M.26 & $\mathrm{B}$ & $\mathrm{A}$ & $\mathrm{A}$ & $\mathrm{A}$ \\
& $71.7 \mathrm{a}$ & $70.8 \mathrm{ab}$ & $78.3 \mathrm{a}$ & $72.0 \mathrm{~b}$ \\
& $\mathrm{~A}$ & $\mathrm{~A}$ & $\mathrm{~A}$ & $\mathrm{~A}$
\end{tabular}

${ }^{z}$ Mean separation within columns (lowercase letters) by Duncan's multiple range

${ }^{y}$ Mean separation within rows (uppercase letters) by Uuncan's multiple range test 
Table 2. Effect of Phytophthora cactorum infection in three rootstocks on apple fruit production (7-year average, kilograms/tree) of four scion cultivars.

\begin{tabular}{|c|c|c|c|c|}
\hline \multirow[b]{2}{*}{ Rootstock } & \multicolumn{4}{|c|}{ Scion cultivar } \\
\hline & Delicious & $\begin{array}{c}\text { Golden } \\
\text { Delicious }\end{array}$ & $\begin{array}{l}\text { Haroldred } \\
\text { Delicious } \\
\end{array}$ & McIntosh \\
\hline & \multicolumn{4}{|c|}{ Yield (kg/tree) } \\
\hline M.111 & $\begin{array}{l}13.3 \mathrm{a}^{\mathrm{z}} \\
\mathrm{B}^{\mathrm{y}}\end{array}$ & $\begin{array}{c}55.7 \mathrm{a} \\
\mathrm{A}\end{array}$ & $\begin{array}{c}42.4 \mathrm{a} \\
\mathrm{AB}\end{array}$ & $\begin{array}{c}53.3 \mathrm{a} \\
\mathrm{AB}\end{array}$ \\
\hline M.7 & $\begin{array}{c}18.9 \mathrm{a} \\
\mathrm{C}\end{array}$ & $\begin{array}{c}57.1 \mathrm{a} \\
\mathrm{A}\end{array}$ & $\begin{array}{c}22.2 b \\
C\end{array}$ & $\begin{array}{c}39.7 \mathrm{~b} \\
\mathrm{~B}\end{array}$ \\
\hline M.26 & $\begin{array}{c}14.8 \mathrm{a} \\
\mathrm{B}\end{array}$ & $\begin{array}{c}26.0 \mathrm{~b} \\
\mathrm{~A}\end{array}$ & $\begin{array}{c}29.0 \mathrm{~b} \\
\mathrm{~A}\end{array}$ & $\begin{array}{c}21.8 \mathrm{c} \\
\mathrm{AB}\end{array}$ \\
\hline
\end{tabular}

${ }^{2}$ Mean separation within columns (lowercase letters) by Duncan's multiple range test at $P \leq 0.05$.

${ }^{y}$ Mean separation within rows (uppercase letters) by Duncan's multiple range test at $P \leq 0.05$.

tible to $P$. cactorum than M.7 when 'Golden Delicious' was the scion (Table 1). Similarly, M.26 was less susceptible than M.7 when 'McIntosh' was the scion. No difference in susceptibility was observed between the three rootstock when 'Delicious' and 'Haroldred Delicious' were scions (Table 1). These observations indicated that the influence of scion cultivars on rootstock susceptibility to $P$. cactorum crown rot is variable. In one case, M.26 with 'McIntosh', which is considered susceptible, was more resistant than M.7. This result implies that scion-rootstock combinations may play a role in resistance to Phytophthora infection. This finding would have to be supported by more combinations and data. Dakwa and Sewell (1981) showed that MM.111 was more susceptible to $P$. cactorum infection when 'Cox's Orange Pippin' rather than 'Worcester Pearmain' was the scion.

Generally, 'Golden Delicious' produced high apple yields with all three rootstock (Table 2). Interestingly, although the percent- ages of infection in rootstock were high, fruit production was not greatly affected. For example, on average, $71 \%$ of the area was affected by crown rot in rootstock with 'Golden Delicious' scions, but production per tree was high for this scion. Most of the trees appeared healthy and produced fruit until 1990. It appears that a substantial $P$. cactorum infection may be necessary before a tree becomes nonproductive or is killed.

\section{Literature Cited}

Barritt, B.H., R.P. Covey, and M.A. Dilley. 1990. In vitro testing of the reaction of apple rootstock to Phytophthora cactorum. Fruit Var. J. 44:23-25.

Borecki, Z. and D.F. Millikan. 1969. A rapid method for determining the pathogenicity of Phytophthora cactorum. Phytopathology 59:247-248.

Cummins, J.N. and H.S. Aldwinckle. 1982. New and forthcoming apple rootstock. Fruit Var. J. 36:66-79.

Dakwa, J.T. and G.W.F. Sewell. 1981. Influence of rootstock type and time of inoculation on the resistance of five apple scion cultivars to collar rot caused by Phytophthora cactorum. J. Hort. Sci. 56:357-362.

Harris, D.C. 1990. Crown rot (Phytophthora cactorum) of apple in Britain: Observations on natural outbreaks, and experiments on artificially inducing the disease in the field. J. Hort. Sci. 65:627-637.

Harris, D.C. and K.R. Tobutt. 1986. Factors influencing the mortality of apple seedlings inoculated with zoospores of Phytophthora cactorum (L. \& C.) Schroet. J. Hort. Sci. 61:457-464.

Matheron, M.E., D.J. Young, and J.L. Matejka. 1988. Phytophthora root and crown rot of apple trees in Arizona. Plant Dis. 72:481-484.

McIntosh, D.L. 1975. Proceedings of the 1974 APDW Workshop on crown rot of apple trees. Can. Plant Dis. Survey 55: 109-116.

Sewell, G.W.F. and J.F. Wilson. 1959. Resistance trials of some apple rootstock varieties to Phytophthora cactorum (L. \& C.) Schroet. J. Hort. Sci. 34:51-58.

Sewell, G.W.F. and J.F. Wilson. 1973a. Phytophthora collar rot of apple: Seasonal effects on infection and disease development. Ann. Applied Biol. 74:149-158.

Sewell, G.W.F. and J.F. Wilson. 1973b. Phytophthora collar rot of apple: Influence of the rootstock on scion variety resistance. Ann. Applied Biol. 74:159-169.

Sewell, G.W.F. and J.F. Wilson. 1974. Seasonal factors and Phytophthora collar rot. E. Mailing Res. Sta. Annu. Rpt. 1973:183-185.

Tobutt, K.R. 1985. Breeding columnar apples at East Malling. Acta Hort. 159:63-68.

Utkhede, R.S. 1984. The effect of nitrogen fertilizers and wood composts on the incidence of apple crown rot in British Columbia. Can. J. Plant Pathol. 6:329-332.

Utkhede, R.S. 1986. Biology and control of apple crown rot caused by Phytophthora cactorum: A review. Phytoprotection 67:1-13.

Utkhede, R.S. and H.A. Quamme. 1988. Use of the excised shoot assay to evaluate resistance to Phytophthora cactorum of apple rootstock cultivars. Can. J. Plant Sci. 68:851-857. 